Syntax Fusion : Jurnal Nasional Indonesia

P-ISSN: $x x x x-x x x x$

e-ISSN : $x x x x-x x x x$

Vol. 1, No. 1, Oktober 2020

\title{
GROUPTHINK DALAM PEMBUATAN KEPUTUSAN KEGIATAN BINA DESA KELOMPOK MAHASISWA PECINTA ALAM
}

\author{
Wita Nurhayati \\ Sekolah Tinggi Agama Islam (STAIPI) Bandung \\ E-mail: ellwhita@gmail.com
}

Abstrak

Penelitian sederhana ini ingin mengetahui apakah terdapat gejala atau proses Groupthink dalam kelompok pecinta alam ini atau tidak, selain itu juga membuktikan perihal tingkat kohesivitas yang tinggi dalam kelompok pecinta alam tersebut. Pada penelitian ini, proses terjadinya Groupthink ditinjau dari kelompok pecinta alam ini dalam merumuskan kegiatan dakwah yaitu Bina Desa. Bina Desa ini merupakan salah satu kegiatan dakwah yang diadakan atau salah satu program kegiatan dakwah dari kelompok pecinta alam ini. Adapun metode yang digunakan dalam penelitian ini adalah metode deskriptif, di mana pengolahan data diambil dari fakta-fakta yang tampak dan disertai dengan adanya pembagian kusioner untuk mempermudah medapatkan hasil yang sesuai. Penelitian ini dibantu dengan responden 15 orang sebagai sample, akan tetapi hanya13 responden yang memberikan jawaban, lalu responden diambil dari anggota mahapala itu sendiri dari berbagai generasi. Selanjutnya hasil dari penelitian sederhana ini, dapat dikatakan bahwa ada proses atau gejala Groupthink terjadi pada kelompok pecinta alam ini. Namun memang hanya terjadi pada salah satu gejala saja dari keempat gejala, yaitu tentang penilaian berlebihan terhadap kelompok itu sendiri. Selain itu juga tingkat kohesivitas yang timbul dari kelompok ini juga sangat tinggi, karena dengan terjadinya salah satu gejala tersebut bisa menjadi alasan tersendiri dalam meningkatnya kohesivitas pada kelompok pecinta alam ini. Terakhir tentang pengambilan keputusan itu sendiri secara dominan responden menyatakan bahwa kelompok pecinta alam mengambil keputusan dengan menggunakan cara musyawarah..

Kata Kunci: Groupthink, Komunikasi, Kelompok Mahasiswa Pecinta Alam

\section{Pendahuluan}

Komunikasi merupakan aktivitas yang tidak bisa dihindari oleh makhluk hidup, khusunya manusia. Aktivitas tersebut terjadi tidak hanya kepada diri sendiri tetapi terhadap orang lain melalui interaksi satu sama lain. Komunikasi juga bisa terjadi di mana saja, kapan saja dan dengan siapa saja, termasuk komunikasi yang terjadi di dalam sebuah kelompok atau sebuah organisasi. 
Dalam sebuah kelompok atau komunitas apapun perihal komunikasi akan selalu mewarnai baik itu perkembangannya maupun hal-hal apapun yang terjadi dalam kelompok tersebut. Tidak ada satu kelompok di manapun yang tidak ada aktivitas tersebut, mustahil bahkan bisa dikatakan mati kelompok tersebut.

Aktivitas komunikasi yang terwujud dalam suatu kelompok, di mana para anggotanya memiliki persamaan nilai, rasa atau hobi yang sama. Hal-hal demikian yang biasanya dapat mempengaruhi karena memiliki banyak kesamaan, atau juga karena kelompok tersebut dianggap unggul dengan kelompok lainnya.

Adapun tentang komunikasi kelompok, seperti yang tertulis dalam jurnalnya (Siregar, 2013), pada sumber tersebut dikatakan bahwa Michael Burgoon mendefinisikan komunikasi kelompok merupakan proses interaksi dengan cara tatap muka secara langsung, baik itu tiga orang atau lebih dari itu. Di mana dalam interaksi tersebut sudah diketahui tujuannya, seperti bertukar atau berbagi informasi lalu pemecahan masalah sampai perihal menjaga diri. Akan tetapi dalam kelompok apapun tentu selalu ada saja proses kegagalan dalam berkomunikasi, dan salah satu faktornya ialah kurangnya sikap dalam mendengarkan dengan empati, seperti yang dikatakan Floyd (1985) bahwa sikap empati menjadi kunci untuk menjaga dalam mendengarkan sehingga terbentuklah komunikasi yang baik.

Seperti yang telah banyak diketahui bahwa kelompok yang memiliki visi-misi bahkan aturan. Sebenarnya kelompok itu tidak sekedar perkumpulan orang-orang saja, tetapi seperti yang telah diutarakan bahwa kelompok dikatakan kelompok karena memiliki tujuan yang jelas dan disepakati bersama. Baron dan Byrne dalam buku (Rakhmat, 2012, p. 139) menyatakan bahwa kelompok memiliki dua tanda psikologis, yaitu yang pertama adalah semua anggota kelompok memiliki rasa keterikatan dengan kelompok (sense of belonging) yang di mana rasa itu tidak dimiliki oleh orang yang bukan anggota. Kemudian yang kedua, dikatakan bahwa nasib setiap anggota itu saling bergantung satu sama lain.

Kelompok yang diteliti adalah salah satu komunitas pecinta alam yang di beri nama MAHAPALA JIRIM (Mahasiswa Pecinta Alam Jiwa Rimba) di Bandung. Yang menjadikan salah satu program unggulan yaitu kegiatan sosial Bina Desa. Dalam kegiatan ini dapat dikatakan menjadi sebuah tangtangan untuk berdakwah kepada masyarakat desa.

Bina Desa ini adalah salah satu kegiatan sosial dengan menjadikannya sebuah kegiatan unggul dan keikutsertaan untuk terjun langsung menghadapi situasi di masyarakat agar menjadi lebih baik dengan melaksanakan dakwah itu sendiri. Seperti yang tercantum dalam salah satu jurnal dakwah yang ditulis oleh Enjang AS, bahwa dalam kegiatan dakwah terdapat empat bentuk dakwah, yaitu (1) Tabligh, bentuk ini lebih kepada upaya dalam penerangan atau juga bisa sebagai upaya penyebaran ajaran Islam. (2) Irsyad, bentuk ini berupaya untuk memberikan bimbingan juga penyuluhan tentang ajaran Islam. (3) Tadbir, pada bentuk ini lebih kepada pemberdayaan masyarakat dalam menjalankan ajaran Islam, namun pemberdayaan ini melalui lembaga-lembaga dakwah. (4) Tathwir, bentuk ini berupaya sebagai pemberdayaan 
seperti halnya tadbir, akan tetapi pemberdayaan dalam bentuk ini merujuk kepada kehidupan dan perihal ekonomi keumatan

Terdapat sebagian pendapat bahwa gejala Groupthink ini lebih cocok ditunjukan kepada kelompok-kelompok yang memang menyimpang dari biasanya yang dapat menunjukkan kohesivitas tinggi bahkan tertutup dengan kelompok lain sehingga menjadi banyak anggapan bahwa kelompoknya paling baik tidak sedikit.

Pada salah satu jurnal menyebutkan bahwa Groupthink bisa disebut sebagai proses berkelompok, di mana individu atau anggota di dalam kelompok tersebut dapat membuat sebuh keputusan yang buruk, lalu prosesnya bisa menggunakan aturan-aturan tertentu, namun hal terebut hanya terjadi pada kelompok yang mengalami Groupthink.

Namun ada juga yang berpendapat bahwa proses Groupthink tidak harus selalu terjadi pada kelompok ekstrim atau dalam hal ini menyimpang, karena memang banyak gejala Groupthink ini akan selalu ada pada setiap kelompok apapun, namun mungkin ada beberapa indikasi terjadi sehingga gejala Groupthink tidak terjadi secara dominan. Dalam salah satu sumber dikatakan bahwa Groupthink ini mengacu kepada pemikiran yang gayanya menjadi irasional, sehingga ini menjadi penyebab setiap anggota kelompok membuat keputusan-keputusan yang sifatnya buruk, hal ini dikemukakan oleh Irving Janis (1972). Adapun keputusan yang diambil oleh kelompok ini biasanya digambarkan sebagai kegagalan konyol (fiascos), lalu kekeliruan ceroboh (blunders), dan terakhir yaitu bencana (debacles). Selain itu pada sumber ini dikemukakan tentang hanya terdapat tiga gejala Groupthink yang terajdi pada setiap kelompok. Pertama yaitu tentang penilaian berlebihan teradap kelompok lain (overestimation of the group), kemudian yang kedua ketertutupan pikiran setiap anggota (closed mineded) dan yang ketiga yaitu tekanan untuk mencapai keseragaman (pressures toward uninformity). Namun meskipun demikian, peneliti memberikan perspektif lain tentang terori Groupthink ini.

Adapun penelitian yang ditulis oleh M. Iqbal Lisdi yang memuat penelitian tentang komunitas/ Club motor. M. Iqbal memaparkan tentang kelompok itu sendiri dengan mengacu kepada empat gejala Groupthink yang disebutkkan. Kemudian sama halnya dengan penelitian pada kelompok pecinta alam di kalangan mahasiswa ini, terkait diadakannya kegiatan Bina Desa. Pada penelitian diungkap apakah benar anggota kelompok menganggap bahwa kelompok ini lebih unggul atau tidak dari kelompok lain dan hal-hal lain yang memang berhubungan dengan gejala Groupthink. Namun adapun kemiripan penelitian yang dilakukan oleh M. Iqbal, yaitu mengungkap adalah gejala Groupthink yang terjadi pada kelompok pecinta alam ini dalam proses kegiatan Bina Desa, akan tetapi tentu saja penelitian pada kelompok pecinta alam ini tidak begitu komprehensif dan lebih sangat sederhana.

Groupthink yang dikemukakan oleh Irving Janis sebagai tokoh yang memperkenalkan teori ini. Janis mengemukakan bahwa Groupthink merupakan sebuah proses dalam pengambilan sebuah keputusan, ini biasanya terjadi pada kelompokkelompok yang memiliki tingkat kohesivitasnya sangat tinggi juga setiap anggotanya 
pun mempertahankan konsensus kelompok, hal tersebut mempengaruhi pula pada kemampuan kritis tidak efektif lagi (Makalah Teori Komunikasi Organisasi).

Selanjutnya tentang gejala-gejala Groupthink yang tedapat dalam sumber lain terdapat empat gejala dan sering terjadi di setiap kelompok manapun, meskipun secara umum gejala dari Groupthink ini hanya memilki tiga gejala. Dalam jurnalnya Lisdi dikemukakan keempat gejala tersebut, yaitu penilaian terhadap kelompok, ketertutupan pikiran anggota kelompok, lalu adanya tekanan mencapai keseragaman anggota kelompok dan yang terakhir pencarian kesepakatan terlalu dini. Akan tetapi pada sumber lain Lisdi sebagai salah satu tokoh dalam teori grouthink ini, menyebutkan terdpat delapan gejala dalam proses terjadinya Groupthink, yaitu invulnerability (kekebalan), rationale (alasan/ rasional), moralality (moralitas), stereotip (stereotif), pressure (tekanan), self-ceshorship (sensor diri), unanimity (kebulatan suara), dan mindguards (penjaga pikiran).

Berbicara tentang kelompok yang kohesif atau memiliki kohesivitas tinggi, ini bukanlah sesuatu hal yang negatif. Terlepas dalam kohesivitas kelompok ini ada kekurangan dan kelebihannya. Adapun arti dari kohesivitas itu sendiri yang diutarakan oleh Collins dan Raven dalam bukunya (Rakhmat, 2012, p. 162) yaitu sebuah kekuatan yang mendorong anggota kelompok, di mana dorongan tersebut mengharuskan tetap tinggalnya anggota kelompok di dalam kelompok dan juga mencegah agar tidak meninggalkan kelompok tersebut.

Berbicara Groupthink dan kohesivitas adalah membicarakan kekompakan sebuah kelompok dan kepuasaan. Sama halnya dengan yang dikatakan oleh (Rakhmat, 2012, p. 162) bahwa kohesif kelompok memiliki hubungan erat dengan kepuasaan. Adapun harapan dalam penelitian ini, mampu membuka pikiran para anggota Mahapala khusunya. Terkait hal-hal yang dianggap kurang baik dalam kelompok tersebut dapat dirubah menjadi semakin baik, meskipun hakikatnya ingin ideal dalam sebuah kelompok tentu akan ada kekurangannya.

\section{Metode Penelitian}

Metode yang digunakan dalam penelitian ini yaitu metode deskriptif, di mana pengolahan data digambarkan sesuai dengan fakta-fakta yang ada. Namun dibantu juga dengan disebarkannya beberapa pertanyaan sederhana dengan maksud dapat membantu penelitian ini. Pertayaan tersebut diberikan kepada 15 orang responden dari anggota Mahapala yang berbeda-beda generasi sebagai sampel penelitiaan.

\begin{tabular}{|c|c|c|c|c|}
\hline Eka & G 1 & G 2 & G 3 & G 4 \\
\hline Berani & Pidak & Mengutarakan & $\begin{array}{c}\text { Menerima } \\
\text { masukan }\end{array}$ \\
\hline Linda & $\begin{array}{c}\text { Sedikit } \\
\text { Berani }\end{array}$ & $\begin{array}{c}\text { Tidak } \\
\text { Pernah }\end{array}$ & $\begin{array}{c}\text { Diam, ikut } \\
\text { saja }\end{array}$ & $\begin{array}{c}\text { Menerima } \\
\text { masukan }\end{array}$ \\
\hline Asipa & $\begin{array}{c}\text { Tidak } \\
\text { Berani }\end{array}$ & Pernah & $\begin{array}{c}\text { Diam, ikut } \\
\text { saja }\end{array}$ & Menerima \\
\hline
\end{tabular}




\begin{tabular}{|c|c|c|c|c|}
\hline & & & & masukan \\
\hline Rahma & Berani & $\begin{array}{l}\text { Tidak } \\
\text { Pernah }\end{array}$ & Mengutarakan & $\begin{array}{l}\text { Menerima } \\
\text { masukan }\end{array}$ \\
\hline Yusuf & Berani & $\begin{array}{l}\text { Tidak } \\
\text { Pernah }\end{array}$ & Mengutarakan & $\begin{array}{c}\text { Menerima } \\
\text { masukan }\end{array}$ \\
\hline Santi & Berani & $\begin{array}{l}\text { Tidak } \\
\text { Pernah }\end{array}$ & Mengutarakan & $\begin{array}{l}\text { Menerima } \\
\text { masukan }\end{array}$ \\
\hline Dina & $\begin{array}{l}\text { Tidak } \\
\text { Berani }\end{array}$ & $\begin{array}{l}\text { Tidak } \\
\text { Pernah }\end{array}$ & $\begin{array}{l}\text { Diam, } \\
\text { tertekan }\end{array}$ & $\begin{array}{c}\text { Menerima } \\
\text { masukan }\end{array}$ \\
\hline Shodiq & Berani & $\begin{array}{l}\text { Hampir } \\
\text { Pernah }\end{array}$ & Mengutarakan & $\begin{array}{c}\text { Menerima } \\
\text { masukan }\end{array}$ \\
\hline Irul & Berani & $\begin{array}{l}\text { Tidak } \\
\text { Pernah }\end{array}$ & $\begin{array}{l}\text { Diam, ikut } \\
\text { saja }\end{array}$ & $\begin{array}{l}\text { Menerima } \\
\text { masukan }\end{array}$ \\
\hline Novi & $\begin{array}{l}\text { Tidak } \\
\text { Berani }\end{array}$ & $\begin{array}{l}\text { Hampir } \\
\text { Pernah }\end{array}$ & Mengutarakan & $\begin{array}{l}\text { Menerima } \\
\text { masukan }\end{array}$ \\
\hline Rosiana & Berani & $\begin{array}{l}\text { Hampir } \\
\text { Pernah }\end{array}$ & Mengutarakan & $\begin{array}{l}\text { Memberi } \\
\text { usul/ ide }\end{array}$ \\
\hline Lisa & Berani & $\begin{array}{l}\text { Hampir } \\
\text { Pernah }\end{array}$ & Mengutarakan & $\begin{array}{c}\text { Menerima } \\
\text { masukan }\end{array}$ \\
\hline Sopian & Berani & $\begin{array}{l}\text { Hampir } \\
\text { Pernah }\end{array}$ & Mengutarakan & $\begin{array}{c}\text { Disanggah/ } \\
\text { iya-iya } \\
\text { saja }\end{array}$ \\
\hline
\end{tabular}

\section{Hasil dan Pembahasan}

Seperti yang diungkap oeh Mulyana (2005), dikatakan bahwa kelompok ini merupakan kumpulan orang-orang yang memiliki tujuan yang sama dan saling berinteraksi satu sama lain sesama anggota kelompok pecinta alam. Begitupun dengan kelompok pecinta alam dalam penelitian ini, merupakan sekumpulan mahasiswa pecinta alam yang memiliki hobi sama dalam kegiatan mendaki gunung, namun disamping itu juga kelompok pecinta alam ini aktif dalam kegiatan-kegiatan yang bertemakan dakwah termasuk ketika mendaki gunung.

Awal dimulainya kegiatan ini, sudah banyak kegiatan-kegiatan yang dilakukan. Namun pada pelaksanaan di tahun 2017, nama kegiatan ini menuai banyak dukungan dan masukan oleh komunitas atau organisasi lain bahkan dari sekitaran dosen dan mahasiswa. Kegiatan ini dilaksanakan di wilayah yang tidak banyak diketahui oleh orang-orang karena akses yang sulit dilalui oleh kendaraan roda dua, juga medan jalan yang melewati perbukitan.

Kedua kegiatan di atas merupakan kegiatan yang dapat dikatakan unggul dari 
program kelompok pecinta alam yang dilaksanakan oleh para mahasiswa tersebut. Namun kegiatan yang bermuatan nilai dakwah dan menjadi fokus penelitian ini adalah kegiatan Bina Desa. Penelitian ini tetap fokus pada apakah terjadi gejala Groupthink dalam kelompok pecinta alam ini dalam merumuskan proses kegiatan Bina Desa. Gejala-gejala yang timbul akan mempengaruhi pada proses pengambilan keputusan yang terlihat dari kelompok pecinta alam ini. Penelitian ini akan mengungkap seberapa kuat para anggota memandang kelompok ini, lalu juga adakah anggota yang berani untuk meninggalkan perkuliahan untuk kegiatan Bina Desa ini, kemudian juga bagaimana sikap para anggota dalam merumukan segala hal yang berkaitan dengan pelaksanaan program-programnya.

Sedikit mengulas salah satu program unggulan dari kelompok pecinta alam ini, yaitu kegiatan Bina Desa ternyata sudah lama pula diadakan, sedikit melakukan wawancara sederhana kepada pembimbing kelompok pecinta alam ini beliau mengungkap bahwa adanya acara atau program Bina Desa ini bermula pada hobi bertualang ke berbagai pelosok atau daerah terpencil. Mulai tahun 1998 kegiatan ini belangsung, namun tentu proses dan konsep yang ada pembaharuan dari tahun ke tahun. Pembimbing ini juga mengatakan bahwa ketika bertualang ke pelosok banyak menemukan fenomena-fenomena yang menghawatirkan dan sampai pada saat ini pembimbing berharap ada yang terus-menerus melanjutkan.

Adapun fenomena yang mengkhawatirkan dari masyarakat pelosok yaitu kurang tersentuh baik dari segi ilmu maupun moril dan tentu yang menjadi sorotan utama adalah kurangnya tersentuh dari ilmu-illmu agama, oleh sebab itu perlulah kegiatan ini dengan tujuan dakwah kepada masyarakat. Pembimbing kelompok ini pun mengungkapkan harapan dari diadakannya kegiatan ini selain dari tujuan utama yaitu dakwah, harapannya mampu berbagi kasih bersama dan tumbuhnya motivasi di kalangan generasi muda di desa.

Dapat dikatakan bahwa kegiatan Bina Desa ini sebagai salah satu strategi dalam melebarkan sayap dakwah yang diisi oleh kalangan muda yaitu para mahasiswa pecinta alam. Tentu pada proses kegiatan Bina Desa tersebut, ada harapan-harapan tertentu yang dapat timbul dari masyarakat binaannya, semisal adanya perubahan-perubahan tertentu yang mucul pada diri atau masing-masing pribadi yang ada di masyarakat tersebut.

Problematika adanya perubahan sosial yang keluar dari aturan, menyebabkan dakwah ini sangat dibutuhkan sehingga jelaslah bahwa dengan adanya kegiatan Bina Desa terhadap kelompok masyarakat terpecil sangat baik dilakukan guna berbagi ilmuilmu agama agar dengan ilmu tersebut masyarakat mampu menyaring semua hal yang akan mempengaruhi. Seperti yang banyak dikemukakan dalam beberapa literasi bahwa masyarakat sebagai kumpulan individu-individu tentu membutukan adanya individu lain, hal ini merupakan ciri bahwa manusia di manapun posisinya adalah sebagai makhluk sosial.

Kemudian dengan adanya kegiatan Bina Desa ini, bisa menjadi satu hal yang saling memberikan pengaruh dalam meningkatkan kualitas hidup seorang individu. Dalam hal ini, ketika kelompok pecinta alam ini berbagi imu dan berbagi apapun kepada 
masyarakat binaannya, hal tersebut merupakan proses peningkatan kualitas hidup para anggota kelompok pecinta alam. Lalu pada satu sisi lain, kelompok pecinta alam ini menjadi sebuah perantara tersendiri untuk masyarakat Bina Desa tersebut dalam hal meningkatkan kualitas hidupnya. Bahkan Islam pun mengajarkan demikian, baik yang memang berkaitan dengan dunia yang sedang di jalani maupun kehidupan akhirat yang akan di jalani kelak.

Jika merujuk kepada empat bentuk kegitan dakwah, pada kegiatan Bina Desa ini tampak dua bentuk yang dominan yaitu irsyad yang membimbing masyarakat dan juga tathwir sebagai bentuk pemberdayaan mayarakat dari segi perubahan kehidupan. Tentu kegiatan pemberdayaan masyarakat ini pun tidak terlepas dari bantuan-anuan masyarakat lain yang menitipkan sebagian bantuannya kepada kelompok pecinta alam ini untuk disalurkan kepada masyarakat binaanya. Zaidan (1979: 98) mengatakan bahwa Dakwah Islam itu menentukan tegak atau runtuhnya masyarakat dan ini akan terbantu oleh adanya suatu jama'ah dan untuk membangun masyarakat tidak bisa jika tanpa adanya sebuah proses dakwah.

Selanjutnya program kegiatan apapun dan dilaksanakan oleh kelompok atau organisasi apapun tentu akan melewati musyawarah atau dengan berdiskusi agar dapat terjalin komunikasi sesma kelompok. Pada prosesnya tersebut dicari tahu melalui penelitian ini dalam mengungkap seberapa jauh gejala Groupthink ini terjadi pada kelompok pecinta alam ini yang fokus dalam merumuskan kegiatan Bina Desa.

Selain itu kebutuhan dakwah sebagai media penyebaran ilmu-ilmu agama terhadap masyarakat kecil, memang harus dijadikan sorotan tersendiri bagi semua umat manusia yang diberikan keleluasaan waktu dan ilmu. Seperti dalam salah satu literasi bahwa ketika masyarakat dijadikan sebagai obejk atau sasaran dakwah, hal tersebut menjadi salah satu unsur penting dalam sistem dakwah bahkan karena kepentingannya tersebut dapat dikatakan peranannya tidak kalah perlu dibanding unsur yang lain.

Seperti yang telah dikemukakan bahwa terdapat empat gejala dalam Groupthink, di mana empat gejala ini akan berimbas pada bagaimana satu kelompok mengambil keputusan. Pada hal ini kelompok pecinta alam dari para mahasiswa tersebut akan mengungkap terkait gejala-gejala Groupthink yang terjadi khususnya gejala ini akan berimbas pada kegiatan Bina Desa. Meskipun pada salah satu sumber dituliskan bahwa West dan Turner (2009:276) memberikan komentar tentang konsep Groupthink, keduanya mengungkap bahwa di dalam Groupthink ini terjadi rendahanya sebuah kepedulian antar anggota kelompok terhadap ide-ide (alternatif) dibandingkan dengaan sebuah ide (utama atau mayoritas).

Pada gejala pertama, yaitu tentang penilaian berlebihan terhadap kelompok diketahui dari 13 responden yang memberikan jawabannya, menunjukkan adanya gejala Groupthink pada kelompok ini menilai berlebihan. Hal ini dibuktikan dengan diajukannya sebuah pertanyaan yang mempertanyakan soal keberanian, keberanian anggota dalam kelompok pecinta alam ini memilih untuk berani meninggalkan kuliah untuk pergi dalam melaksanakan kegiatan Bina Desa tersebut. Akan tetapi hasil dari penelitian pada gejala ini dominan adalah yang mengatakan berani untuk meninggalkan 
pembelajaran. Selain itu terdapat alasan lain dengan jawaban para responden tentang kejujuran dari masing-masing pribadi dalam menilai kelompok pecinta alam tersebut. Apabila merujuk kepada hal ini, memang dari ke-13 responden memberikan hasil tidak dominan dalam memberikan penilaian berlebih kepada kelompoknya. Hal ini dibuktikan dengan jumlah responden yang hanya 4 orang mengakui sepenuhnya menganggap kelompok ini paling baik, lalu apabila keyakinan ini di analogikan kedalam persentase ke 4 orang responden ini memberikan angka $100 \%$ dalam hal menilai berlebihan kepada kelompoknya.

Kemudian terdapat 3 responden yang memberikan angka 75\% dan sisanya 6 responden memberikan 50\% dalam menilai bahwa kemlompok ini paling baik dari kelompok lain. Kemudian, bila peneliti mengambil angka $75 \%$ itu termasuk orang yang memandang berlebihan kepada kelompok pecinta alam ini, dapat diasumsikan bahwa perihal jawaban dari kejujuran yang diutarakan menunjukan pada gejala pertama ini terjadi proses Groupthink. Namun yang menjadi catatan pada gejala ini, bahwa pada kelompok ini meskipun kegiatan yang dijalani adalah kegiatan dakwah Islam yang jelas kepositifannya, akan tetapi terjadi proses Groupthink yang pada literasi lain sering kali proses ini terjadi pada kelompok yang menyimpang bahkan berbeda dengan kebiasaan pada umumnya.

Jika dilihat dari salah satu kondisi Groupthink yang dikemukakan oleh Janis dan Lumsdem pada salah satu sumber, berkaitan dengan gejala pertama ini yaitu kondisi kohesivitas. Jika dikatakan bahwa kondisi ini merupakan sebuah perekat antara sesama anggota kelompok dan juga rasa ketertarikan satu sama lain. Membicarakan ketertarikan sesama anggota kelompok yang kuat, tentu ini berbicara soal seberapa tinggi kenyamanan anggota berada di kelompok tersebut, dengan demikian hal ini juga bisa menjadi sebuah alasan beberapa anggota kelompok pecinta alam ini menunjukkan penilaia berlebihan kepada kelompoknya sendiri, yaitu karena timbul dari tingginya rasa kenyamanan tersebut, meskipun itu timbul dari sesama anggota kelompoknya.

Kemudian pada salah satu kesempatan lain diketahui bahwa pada kelompok ini terjadi penilaian berlebihan pada kelompok sendiri, ini terbukti dari pernyataan para anggota yang menyebutkan bahwa kelompok Mahapala ini sangat berpengaruh kepada kehidupan para anggotanya. Memang ada pula yang menyebutkan biasa-biasa saja, namun pernyataan tentang sangat berpengaruhnya kelompok ini peneliti memiliki asumsi tersendiri bahwa para anggota memiliki rasa lebih terhadap kelompok Mahapala ini.

Pada literasi lain dikatakan tentang indikasi yang lebih spesifik di dalam gejala Groupthink pertama ini, yaitu (1) Ilusi Kekebalan (Illusions of invulnerability), hal ini menunjukkan adanya optimisme yang berlebihan sehingga menimbulkan terjadinya sebuah resiko yang diambil oleh anggota kelompok pecinta alam ini. Namun pada salah satu jurnal disebutkan bahwa (Mitchel, 2009:166) memberikan pendapat tentang hal ini, karena ilusi yang menyebabkan adanya optimisme berlebihan, menyebabkan anggota kelompok membuat keputusan yang buruk. Jika melihat hal demikian, memang lebih cocok dikemukakan pada kelompok-kelompok yang menyimpang, akan tetapi pada 
kelompok ini tidak begitu saja menyimpukan bahwa anggota kelompok yang memilih untuk kegiatan Bina Desa itu membuat keputusan yang buruk, karena sudah jelas kegiatan ini adalah bagian dari dakwah. (2) (Unquestioned Belief) yaitu tentang tingginya kepercayaan yang terjadi pada moralitas kelompok. Hal ini timbul dalam tindakan yang diambil.

Selain itu juga, responden ini lebih dominan menyatakan bahwa tidak adanya ketertutupan dalam menyatakan ide atau pendapat dalam kegiatan apapun dalam kelompok ini. Namun gejala ini pun ada karena seperti yang diketahui bahwa dalam setiap kelompok tentu terjadi ketertutupan pikiran anggota kelompok terhadap kelompok, namun pada penelitian ini tidak begitu mendominasi.

Meskipun demikian hasil dari gejala ini, akan tetapi apabila melihat kepada 1 orang responden tersebut ini dapat sesuai dengan kondisi lain dari gejala Groupthink. Jika gejala pertama lebih kepada kondisi kohesivitas, gejala kedua ini terlihat pada kondisi Struktular Kelompok denga catatan melihat jawaban 1 responden, di mana sebagai sample tidak menutup kemungkinan ada beberapa anggota lain yang memberikan jawaban yang sama. Kondisi Struktur Kelompok ini, menunjukkan homogenitas kelompok, proses kelompok yang tidak memadai dan juga adanya isolasi dari luar. Ketiga hal dalam Struktur Kelompok tersebut, apabila dipersempit responden yang dimaksud lebih dominan pada aspek isolasi dari luar, ini terbukti dengan jawabannya yang sampai pernah menutup diri dari masukan-masukan dari luar. Sehingga timbul kurangnya dalam menerima informasi karena ketertutupan tersebut.

Selanjutnya apabila dilihat dari sisi spesifiknya gejala ini, menunjukan adanya stereotif kelompok luar dan rasionalisasi kelompok. Namun keduanya menunjukkan tanggapan-tanggapan negatif kepada kelompok luar, atau dengan kata lain gejala yang lebih spesifik ini memang lebih cocok untuk kelompok yang menyimpang. Akan tetapi, tidak menutup kemungkinan bahwa ada beberpa anggota yang memiliki pemikiran demikian, namun hal ini belum bisa dibuktikan karena butuhnya penelitian lebih mendalam.

Tampak dari hasil penelitian yang ada pada jawaban tentang gejala ini yaitu gejala ketiga tentang tekanan mencapai keseragaman anggota kelompok, terindikasi tidak terjadi Groupthink pada gejala ketiga ini. Hal ini dikarenakan dominan responden mengungkapan selalu bebas dan aktif dalam memberikan masukan dan ide-ide yang muncul dari anggota pecinta alam tersebut dalam membicarakan kegiatan Bina Desa. Sehingga memang tidak terjadi Groupthink, terlebih dari 13 responden memilih untuk selalu mengutarakan ide-idenya meskipun berujung kepada keputusan ketua kelompok tersebut. Adapun sisa responden mengutarakan bahwa memilih untuk diam dalam proses pencapain keseragaman, dalam hal ini tentang mengutarakan ide untuk kelompok dari anggota kelompok. Selain itu juga terdapat 1 responden yang mengungkapkan bahwa lebih memilih diam sampai merasa tertekan karena ada hal yang ingin diutarakan namun memilih untuk diam. Jelas pada gejala ini memang tidak ada tekanan sama sekali pada diri masing-masing anggota, sehingga asumsi bahwa tidak ada Groupthink pun tampak dari jumlah mayoritas responden. 
Tentu pada gejala ini pun terdapat gejala grouthink yang lebih spesifik, di dalam salah satu sumber terdapat empat poin tentang hal ini. (1) Sensor diri (self-censorship), poin ini menunjukkan adanya kecenderungan dalam meminimalkan argument atau pendapat pribadi terhadap pendapat yang menjadi mayoritas pada kelompok tersebut, juga bisa dikatakan para anggota lebih memilih bungkam terhadap pemikirannya sendiri (West dan Turner, 2009:284). (2) (Illusion of unanimity) atau tentang adanya kebulatan suara yang semu. Maksud dari poin ini yaitu adanya anggapan bahwa ketika anggota memilih diam dalam proses diskusi itu merupakan tanda setuju, selain itu meskipun ada pemikiran atau pendapat yang berbeda dari anggota kelompok terhadap pemimpinnya, akan tetapi memilih untuk diam inilah yang menyebabkan adanya anggapan bahwa anggota telah sepakat dan terjadi kebulatan suara. Menurut West dan Turner (2009:285) ilusi seperti ini menimbulkan adanya suatu keputusan yang palsu. (3) Self-appointed mindguards, pada poin ketiga pada gejala ini lebih kepada sikap anggota kelompok yang memberikan perlindungan, adapun perlindungan tersebut ditujukan kepada kelompoknya dari berbagai informasi yang tidak mendukung kelompok yang sedang dilindunginya. Selai itu juga anggota kelompok pada poin ini memiliki keyakinan sikap atau tindakannya tersebut merupakan pembelaan atau demi kepentingan kelompoknya. (4) Tekanan terhadap para penentang (pressures on dissenters), poin ini yaitu berupa pengaruh atau berupa tekanan yang diarahkan kepada anggota-anggota kelompok yang memberikan pendapat, pandangan juga opini dan di mana semua hal tersebut berlawanan dengan opini mayoritas kelompoknya.

Selanjutnya apabila ditinjau dari aspek kondisi pada gejala Groupthink yang dikemukakan oleh Janis dan Lumsden, lebih kepada kondisi situasi. Adapun maksud dari kondisi situasi ini terjadinya stress yang bersifat situasional dan hal ini juga dapat menyebabkan adanya penekanan sehingga tejadi Groupthink, lalu apabila dalam kelompok tersebut menemui situasi krisis anggotanya cenderung memilih untuk tertutup dalam mengungkapkan ide-ide yang berbeda. Kemudian pada sumber yang sama Chapman dalam Lumsden (2010:283) memberikan pendapatnya tentang hal ini, bahwa ketika seseorang atau dalam anggota kelompok pecinta alam menghadapi rasa cemas, anggota tersebut cenderung mendapatkkan motivasi untuk menemukan kesepakatan dengan anggota kelompok yang lain guna mengurangi rasa gugupnya.

Dengan melihat aspek kondisi tersebut, dapat diasumsikan bahwa responden tersebut yang memilih untuk diam dengan perasaan tertekannya, mengalami aspek situasional yang menyebabkan dirinya sebagai anggota kelompok cenderung tidak memilih untuk mengutarakn ide-idenya. Adapun kondisi ini merujuk kepada Faktor Kepemimpinan, poin ini menunjukkan bahwa apabila pemimpin dalam satu kelompok tertentu bersikap "tidak menyenangkan" tentu akan berpengaruh kepada anggota lain untuk berpendapat. Selain itu juga anggota tersebut meyakini bahwa apa yang akan diutarakannya tidak akan disurakan dan ini berpengaruh dari sikap pemimpin kelompok tersebut. Bisa jadi salah satu responden ini mendapati "rasa" demikian oleh pemimpin kegiatan apapun.

Pada gejala terakhir yaitu sebuah pencarian kesepakatan kelompok yang terlalu 
dini, ini pun tidak terindikasi terjadi Groupthink. Hal ini disebabkan para responden yang mayoritasnya mengutarakan jawaban dengan menerima masukan dari anggota kelompok lainnya. Seperti yang dikatakan sebelumnya bahwa responden pada gejaala ini mendapati posisi mayoritas, sehingga dengan adanya proses saling menerima masukan sesama anggota, tentu tidak akan terjadi proses kesepakaan dalam perumusan kegiatan yang cepat atau terlalu dini. Selain itu juga memang ada beberapa responden mengutarakan ikut saja dengan keputusan yang disepakati tanpa ikut andil dalam memberikan masukan atau menerima masukan sesama anggota kelompok.

Selain itu pada gejala ini tidak nampak karena kelompok pecinta alam ini selalu bermusyawarah dalam menentukan keputusan atau dalam pengambilan keputusan. Hampir semua responden menjawab demikian, di mana kelompok pecinta alam ini mendengarkan semua argument dari para anggotanya. Meskipun ada salah satu responden yang mengatakan dalam pengambilan keputusan meskipun dengan musyawarah mendengarkan ide-ide dari anggota lain, ada keributan-keributan kecil yang terjadi sehingga menganggu keefektifan pengambilan keputusan.

Selanjutnya kembali mengungkap tentang adanya kohesivitas, seperti yang diungkap oleh Janis dan Rakhmat keduanya mengemukakan bahwa adanya Groupthink ini terjadi pada kelompok-kelompok yang memiliki tingkat kohesivitas tinggi di dalam kelompoknya. Proses adanya sebuah rasa kenyamanan sesama anggota kelompok, dapat dikatakan karena adanya sebuah interaksi sosial (hubungan antara manusia dengan manusia lainnya) yang intens, sehingga ada proses penyesuaian diri dari masing-masing anggota untuk saling terbuka dan memahami satu sama lain. Selain itu juga dengan adanya proses interaksi sosial sesama anggota pecinta alam, dengan sendirinya ada kemungkinan untuk memperlihatkan tingkah laku sesama anggota dan apabila terdapat perilaku yang keliru akan mampu mengubahanya dengan proses interaksi tersebut.

Dalam jurnal yang ditulis oleh Irwanti dan Muharman dikemukakan bahwa menurut (vemale.com) tingkat kekuatan wanita berada dalam sebuah group atau kelompok lebih tinggi dibandingkan dengan laki-laki. Tingkat kekuatan tersebut terkadang membuat wanita lebih nyaman. Hal ini senada dengan apa yang terjadi pada kelompok pecinta alam, yang dominan tidak bertahan adalah laki-laki. Kemudian seperti yang tertera dalam beberapa sumber bahwa pengaruh dari tingkat kohesivitas yang tinggi ini menunjukkan adanya Groupthink yang terjadi dalam kelompok tersebut. Kohesivitas pada kelompok pecinta alam ini dinilai sangat tinggi sehingga menimbulkan padangan bahwa adanya Groupthink pada kelompok pecinta alam ini. Namun memang pada hal tersebut, yaitu jika dilihat dari masalah adanya kenyamanan sesama anggota kelompok sampai memiliki tingkat kohesivitas yang tinggi, memang menimbulkan kesimpulan bahwa ada gejala Groupthink terjadi.

Salah satu sumber mengemukakan tentang pembagian hal yang berpengruh pada kohesivitas kelompok, adapaun dianntaranya yaitu aspek loyalitas dan juga aspek solidaritas. Pertama, tentang loyalitas ini lebih mengarah kepada perasaan setia yang dimiliki setiap anggota kelompok dan enggan untuk meninnggalkan kelompoknya tersebut. Kedua, yaitu solidaritas hal ini merupakan perasaan setia yang lebih tertuju 
kepada sesama anggota kelompoknya, ada pemberian perhatian terhadap masalah anggota lainnya. Jika melihat hasil penelitian yang memberikan jawaban tentang rasa nyaman, tentu kedua aspek ini memiliki pengaruh tersendiri untuk hal tersebut.

Gejala-gejala Groupthink yang terjadi sampai tentang kohesivitas kelompok ini tentu memberikan pengaruh tersendiri terhadap bagaimana kelompok ini mengambil keputusan. Seperti yang dituliskan pada sebuah literasi tentang pengambilan atau pembuatan keputusan dari satu kelompok tertentu, yaitu merupakan sebuah proses menetapkan pilihan pendapat sebagai alternatif dari berbagai altermatif dan pilihan yang paling baik diambil berguna untuk pemecahan masalah yang terjadi pada kelompok apapun. Jika sedikit ditela'ah memang terlihat sedikit rumit dalam penentuan baik atau paling baik alternatif itu dipilih. Terkait tentang proses pengambilan keputusan Janis dan Mann (1977) mengemukakan pendapat yang terdapat dalam salah satu sumber, keduanya mengungkap bahwa selama proses pengambilan keputusan pada gejala grouphtink tersebut muncul beberapa hal, yaitu (1) Tekanan langsung, di mana pemimpin tim dan anggota kelompok menerapkan hal tersebut bagi yang menyimpang, (2) Ilusi kebulatan suara, hal ini di mana pemimpin menggap semua anggota kelompok sepakat, (3) Penyensoran sendiri,hal ini anggota memilih untuk diam dan tidak mengekspresikan pandangannya, ketika hasil yang muncul tidak sesuai harapan beberapa anggota.

Meskipun sebelumnya sudah diungkap bahwa pada kelompok ini, dalam merumuskan sesuatu hal tidak terleps dari musyawarah terleih dahulu. Kembali disamping hal demikian, tidak sedikit terjadi atau timbul dari beberapa anggota yang masih mengutamakan ego dalam bermusyawarah. Semisal, kejadian dalam perumusn kegiatan lain yang dibawa ke dalam forum namun ternyata kegiatan yang kan dimusyawarahkan sudah baku dan hanya menjadi bentuk pemberitahuan. Peneliti memberikan asumsi pada hal demikian sebaaik-baik kelompok apapun, sebaik-baik kegiatan apapun yang dilakukan satu kelompok tertentu tidak menjamin pada salah satu anggotanya murni pula, namun tentu meskipun demikian pada kelompok pecinta alam ini tidak sampai pada taraf yang menjadikan pribadinya menyimpang.

Akan tetapi tentu dalam proses penelitian ini tentu banyak sekali menuai kelemahan, baik dari segi sumber atau pun dari cara pengolahan data yang dipandang sangat sederhana.

\section{Kesimpulan}

Kelompok ini dapat dikatakan memiliki beberapa gejala dari Groupthink. Seperti hasil dari penelitian sederhana ini Groupthink hanya terjadi pada gejala pertama yaitu tentang penilaian berlebihan kepada kelompoknya sendiri. Selain itu pada Groupthink pada gejala ini pun semakin kuat dengan jawaban para responden yang menyebutkan bahwa kelompoknya dalam mengadakan kegiatan Bina Desa lebih baik karena mempunyai pengaruh besar terhadap pribadi masing-masing anggota sehingga dengan faktor demikian menimbulkan asumsi bahwa anggota kelompok memiliki penilaian lebih terhadap kelompok pecinta alam tersebut. 
Kemudian untuk gejala yang lain seperti, ketertutupan pikiran anggota kelompok terindikasi tidak terjadi adanya Groupthink karena para anggota sebagai responden dominan mengatakan tidak pernah sampai mengabaikan masukan dari kelompok lain artinya tidak tertutup. Adapula gejala selanjutnya tentang tekanan mencapai keseragaman, hal ini pun terindikasi tidak terjadi Groupthink dikarenakan para anggota pecinta alam ini memilih untuk mengutarakan pendapatnya. Lalu gejala yang terakhir yang terdapat dalam penelitian ini yaitu tentang pencarian kesepakatan terlalu dini, ini pun tidak menimbulkan adanya Groupthink karena anggota kelompok memberikan jawaban yang dominan yaitu selalu menerima masukan dari anggota kelompoknya, sehingga dalam perumusan kegiatan tidak menghasilkan kesepakatan yang dini atau cepat.

Selain itu juga dapat dikatakan ada tidaknya Groupthink pada kelompok ini tampak dari tingkat kohesivitas yang tinggi dan terlihat, sehingga dapat disimpulkan bahwa pada kelompok pecinta alam ini terjadi Groupthink. Terkait kohesivitas ini terbukti dari sikap-sikap atau perilaku anggota yang selain memperlihatkan kenyamanan dalam kelompok juga ada pernyataan langsung dari hasil penelitian yang dilakukan.

Selanjutnya pada kelompok pecinta alam ini, terdapat beberapa kelebihan yang menonjol dari kelompok pecinta alam lainnya. Di samping memiliki struktur organisasi kelompok yang jelas, anggota yang berbeda-beda latar belakang pun mengusung nilai persudaraan yang tinggi. Kelebihan lainnya yaitu kegiatan-kegiatan yang mengutamakan program dakwah, contohnya saja seperti kegiatan "Muncak Bareng" dalam kegiatan ini adalah kegiatan yang tidak sekedar muncak dan menyalurkan hobi sebagai komunitas pecinta alam, tetapi ada kegiatan bedah buku dan juga seminar-seminar yang bertemakan nilai-niali agama Islam.

\section{Bibliografi}

Amran, Ali. (2012 ). Dakwah dan Perubahan Sosial. Jurnal: Hikmah. Vol. VI, No. 01, hlm. 68-86.

AS, Enjang. (2011). Pengembangan Masyarakat Islam Dalam Sistem Dakwah. Jurnal: Ilmu Dakwah, Vol. 5, No. 18 Edisi Juli-Desember.

Burnette, Jeni L, Dkk. (2011). Leadership in Extreme Contexts: Groupthink Analysis of The May 1996 Mount Evrest Disaster. Journal Of Leadership Studies, Vol. 4, Number 4.

Carlson, G.S., (2016). Groupthink. Fort Hays State University, USA.

Chandra R, Syhefira \& Dewi R. (2014). Studi Deskritif Mengenai Groupthink pada Anggota Partai Mahasiswa. Jurnal: Prosiding Penelitian sivitas akademika UNISBA (Sosial dan Humaniora).

Cheshire, William P. (2017). Grouppthink: How Should Clinicians Respond to Human Trafficking?. AMA Journal of Ethic. Volume 19, No. 1, hlm. 91-97.

Faizah dan Lalu Muchsin Effendi. (2015). Psikologi Dakwah. Jakarta: Prenadamedia.

Kusmaryo, Widyanti NS. (2014). Groupthink dan Komunikasi Kelompok Out-Group 
(Studi kasus Fenomena Grupthink dalam Berkomunikasi dengan Kelompok Out-Group di Kalangan Komunitas jali-jali Universitas Sebelah Maret Surakarta). Skripsi.

Kustiwa, Agus Dkk. (2015). Groupthink Theory (Teori Pemikiran Kelompok), Magister Manajemen Komunikasi, Universitas Indonesia.

Kusuma, Tri Angga. (2016). Pengaruh Framing dan Groupthink terhadap Keputusan Pemilihan Karir pada mahasiswa Akuntansi Universitas Airlangga. Skripsi.

Koswara, I \& Slamet M. (2016). Implementasi Model Komunikasi Kelompok Fasilitato Dalam Pelaksanaan Program Rutilahu Di Kota Cimahi. Jurnal Kajian Komunikasi, Volume 4, No. 2, Hlm 199-206.

Lisdi, M. I. (2015). Groupthink dalam Komunikasi Kelompok (Studi Desrkiptif tentang Gejala Groupthink dalam Komunikasi Kelompok Club Motor Brotherhood Medan dalam Rangka Pengambilan keputusan). Jurnal: Ilmu Komunikasi FLOW, 2 (5).

Marlinda, R., \& Muharman, D. (2015). Perspektif Baru Groupthink: Perbedaan Tingkat Pendidikan dalam Proses Pengambilan Keputusan Kelompok. Mimbar, 31(1), 251-260.

Masturi, Ade. (2010). Membangun Relasi Sosial Melalui Komunikasi Empatik (Perspektif Psikologi Komunikasi). Jurnal: Dakwah STAIN Purwekerto, Vol. 4, No. 1, pp. 14-33.

Nurwahidah Alimuddin. (2007). Konsep Dakwah Dalam Islam. Jurnal: Hunafa Vol. 4, No. 1 , hlm. $73-78$.

Rais, A. N., \& Hasanudin. (2017). Komunikasi dan Organisasi, Makalah jurusan Komunikasi dan Penyiaran Islam Program Pascasarjana.

Rakhmat, J. (2012). Psikologi Komunikasi. Bandung: Remaja Rosdakarya.

Riccobono, F. Dkk. (2016). Groupthink and Project Performance: The Influence of Personal Traits and Interpersonal Ties. Production and Operations Management Society, Vol. 25, No. 4, pp. 609-629.

Rismayanti, Rebekka. (2013). Analisis Dinamika Komunikasi Tim Kerja Public Relations Berdasarkan Groupthink Theory (Studi Deskriptif Kualitatif terhadap Kerja Tim Public Relations dalam Perencanaan Event Malam Pergantian Tahun Baru 2013 di Hotel Jayakarta Lombok). S1 Thesis, UAJY.

Tsikerdis, Michail. (2013). The Effects Perceived Anonymity and Anonymity States on Conformity and Groupthinknin Online Communities: A Wikipeda Study. Journal Of American Socitety For Information Science And Technology.

Widiyanto. D. (2010). Pengertian Kohesivitas, diakses pada 1 Desember 2017, dari http://www. google. co. id/amp/s/psikologikelompokwordpress. com/2010/11/21/pengertian-kohesivitas/amp/ 